Fitria Agustina S, Merry Muspita DU dan Ridwan Iskandar, Analisis Pengawasan Dan Kompetensi Terhadap Kepuasan Kerja Karyawan Melalui Kinerja Pada PT. EAST WEST SEED INDONESIA

\title{
ANALISIS PENGAWASAN DAN KOMPETENSI TERHADAP KEPUASAN KERJA KARYAWAN MELALUI KINERJA PADA PT. EAST WEST SEED INDONESIA
}

Oleh :

\section{FITRIA AGUSTINA SIHOMBING *), MERRY MUSPITA DU dan RIDWAN ISKANDAR **)}

\begin{abstract}
ABSTRAK
Perusahaan PT. East West Seed Indonesia adalah perusahaan terbesar dalam bidang produksi benih sayuran lokal di Indonesia. Perusahaan ini memiliki tenaga ahli dalam perkembangan produksi benih dan menciptakan benih - benih sayuran unggul, memiliki mitra dan karyawan yang siap dan mampu dalam meningkatkan kinerja perusahaan, maka dari itu penting bagi perusahaan agar dapat terus memperhatikan dan peduli akan sumber daya manusia, khususnya karyawan yang memiliki kontribusi akan keberhasilan perusahaan dengan cara meningkatkan kepuasan kerja karyawan akan pekerjaannya. Tujuan penelitian untuk mengetahui faktor-faktor yang mempengaruhi kepuasan kerja karyawan PT. East West Seed dengan kinerja sebagai variabel antara. Penelitian ini merupakan penelitian penjelasan dengan menggunakan analisis SEM. Hasil penelitian ini menunjukkan bahwa pengawasan berpengaruh secara langsung dan signfikan terhadap kepuasan kerja, kompetensi berpengaruh secara langsung dan signfikan terhadap kinerja, kemudian kinerja berpengaruh secara langsung dan signifikan terhadap kepuasan kerja karyawan, pengawasan tidak berpengaruh signifikan terhadap kinerja namun kompetensi berpengaruh signifikan terhadap kinerja, jika kinerja sebagai variabel antara sedangkan kompetensi tidak berpengaruh signifikan terhadap kepuasan kerja karyawan baik melalui variabel kinerja maupun tidak melalui variabel kinerja. Berdasarkan hasil analisis dan pembahasan tentang analisis pengawasan dan kompetensi melalu kinerja terhadap kepuasan kerja karyawan PT. East West Seed Indonesia, maka dapat ditarik kesimpulan sebagai berikut: Pengawasan tidak berpengaruh signfikan terhadap kinerja karyawan PT. East West Seed Indonesia dengan nilai $\mathrm{CR}=0,870$ dan $\mathrm{P}$ value $=0.384$. Kompetensi berpengaruh signifikan terhadap kinerja karyawan PT. East West Seed Indonesia dengan nilai $C R=7,456$ dan P value $=0.000$. Pengawasan berpengaruh langsung dan signifikan terhadap kepuasan kerja karyawan PT. East West Seed Indonesia dengan nilai $\mathrm{CR}=3,300$ dan $\mathrm{P}$ value $=0.000$. Kompetensi tidak berpengaruh signifikan terhadap kepuasan kerja karyawan PT. East West Seed Indonesia dengan nilai $\mathrm{CR}=-0,114$ dan P value $=0,909$. Kinerja berpengaruh signifikan terhadap kepuasan kerja karyawan PT. East West Seed Indonesia dengan nilai $\mathrm{CR}=3,085$ dan $\mathrm{P}$ value $=0.002$.

Kata Kunci: PT. East West Seed Indonesia, Kepuasan kerja, Kinerja, Kompetensi, Pengawasan,SEM,
\end{abstract}

\section{PENDAHULUAN}

Setiap perusahaan dalam aktivitasnya berusaha untuk mencapai tujuan yang telah ditentukan. Untuk mencapai tujuan tersebut maka sumber daya yang dimiliki harus dimanfaatkan seoptimal mungkin. Sumber daya yang dibutuhkan untuk menjalankan perusahaan tidak dapat dilihat sebagai bagian yang berdiri sendiri, tetapi harus dilihat sebagai kesatuan yang tangguh membentuk suatu sinergi dalam hal ini peran sumber daya manusia sangat menentukan. Karyawan sebagai sumber daya manusia yaitu tenaga yang bekerja pada perusahaan sangat berperan aktif dalam rangka pencapaian tujuan perusahaan (Sutrisno, 2011).

Fenomena yang sering terjadi pada saat ini diantaranya adalah perhatian perusahaan terhadap kepuasan kerja karyawan semakin menurun atau dapat dikatakan sama sekali tidak memperhatikan kepuasan kerja karyawan pada perusahaan tersebut. Dengan semakin pentingya kepuasan kerja hal ini mempengaruhi kesuksesan perusahaan, perlunya adanya perhatian perusahaan agar tingkat kepuasan kerja karyawan pada perusahaan lebih meningkat, karena itu perusahaan harus memahami bahwa karyawan yang kepuasan kerjanya tinggi akan menghasilkan kinerja yang lebih baik, daripada karyawan dengan kepuasan rendah (Sutarto, 2012).

Salah satu laman pencari kerja yaitu JobStreet.com, dimana JobStreet.com melakukan survei kepada 17,623 koresponden pada awal bulan Oktober 2014 tentang kepuasan karyawan terhadap pekerjaan mereka. Dari hasil survei tersebut menunjukan bahwa $73 \%$ karyawan merasa tidak puas dengan pekerjaannya, dan hal ini terjadi karena beberapa faktor.

PT. East West Seed Indonesia yang merupakan salah satu perusahaan terbesar yang terdapat di Indonesia. Perusahaan ini adalah 
Fitria Agustina S, Merry Muspita DU dan Ridwan Iskandar, Analisis Pengawasan Dan Kompetensi Terhadap Kepuasan Kerja Karyawan Melalui Kinerja Pada PT. EAST WEST SEED INDONESIA

perusahaan benih sayuran terpadu di Indonesia yang menghasilkan benih unggul sayuran melalui kegiatan pemuliaan tanaman. Perusahaan ini mempunyai tujuan utama dalam pengembangan industri benih lokal maupun luar yang unggul untuk menghasilkan benih sayur berkualitas tinggi dan bersertifikat. Dalam meningkatkan produksi perusahaan serta kinerja dari perusahaan, PT. East West Seed Indonesia harus meningkatkan kemampuan sumberdaya manusianya, khususnya mereka para karyawan yang berkerja diperusahaan tersebut mulai dari pengawasan yang dilakukan pimpinan, kompetensi dari pada karyawan , kinerja karyawan sampai pada kepuasan kerja para karyawan.

Kepuasan kerja (job satisfaction) karyawan merupakan hal yang harus diperhatikan oleh pihak perusahaan sebagai upaya memelihara tingkat kinerja karyawan yang diinginkan. Salah satu trend manajemen sumber daya manusia era global ini adalah kemampuan dari perusahaan dalam membangun komitmen bersama karyawannya untuk mendapatkan lebih banyak karyawan yang terlibat dan senang dengan pekerjaannya, sehingga timbul kepuasan kerja yang merupakan suatu pernyataan emosional yang positif atau menyenangkan sebagai akibat dari apresiasi terhadap pekerjaan dan pengalaman kerja karyawan (Siagian, 2007).

\section{KAJIAN PUSTAKA}

\section{Karyawan}

Karyawan sebagai tenaga yang bekerja pada perusahaan sangat berperan aktif dalam rangka pencapaian tujuan perusahaan. Pencapaian tujuan akan berhasil jika karyawan produktif dan berprestasi dalam bekerja dan memiliki kinerja yang tinggi. Oleh karena itu perusahaan harus memberikan timbal balik yang sesuai untuk bisa meningkatkan prestasi karyawan dalam bekerja. Dalam perusahaan karyawan saling berhubungan satu sama lain, membicarakan apa yang menjadi motivasi mereka, pandangan hidup seorang karyawan dan bahkan apa yang menjadi tujuan bersama antara karyawan dan perusahaan. Interaksi dalam perusahaan, didalam pekerjaan timbul karena didasari oleh adanya kesamaan tujuan diantara karyawan - karyawannya. Dengan demikian, perusahaan jangan mengabaikan apa yang menjadi tujuan dan motivasi serta keinginnan dari setiap karyawannya, dengan begitu kepuasan kerja dari diri setiap karyawan bisa terpenuhi

(Umar, 2001).

\section{Pengawasan}

Menurut Bambang (2002) Pengawasan kerja adalah proses pemantauan, penilaian, dan pelaporan rencana atas pencapaian tujuan yang telah ditetapkan untuk tujuan korektif guna penyempurnaan lebih lanjut. Menurut Nitisemito (2002) pengawasan kerja adalah sebagai suatu usaha untuk dapat mencegah kemungkinan kemungkinan terjadinya penyimpangan dari rencana, instruksi-instruksi, saran-saran dan sebagainya yang telah ditetapkan oleh suatu perusahaan atau perusahaan terhadap karyawannya.

3. Kompetensi

Kompetensi merupakan suatu kemampuan yang dilandasi oleh keterampilan dan pengetahuan yang didukung oleh sikap kerja serta penerapannya dalam melaksanakan tugas dan pekerjaan ditempat kerja yang mengaju pada persyaratan kerja yang ditetapkan perusahaan. Kompetensi merupakan kemampuan personal dalam melakukan pekerjaannya agar mendapatkan hasil dengan baik (Eko, 2004).

\section{Kinerja}

Kinerja karyawan adalah seberapa banyak karyawan memberi kontribusi kepada perusahaan yang antara lain termasuk kuantitas output, kualitas output, jangka waktu output, kehadiran di tempat kerja dan sikap komperatif (Damayanti, 2013).

5. Kepuasan kerja

Kepuasan kerja adalah suatu perasaan menyenangkan, merupakan hasil dari persepsi karyawan dalam rangka menyelesaikan pekerjaan atau memenuhi kebutuhannya untuk memperoleh nilai - nilai kerja yang penting bagi diri karyawan (Sutarto, 2012).

Terdapat bermacam-macam pengertian atau batasan tentang kepuasan kerja. Pertama, pengertian yang memandang kepuasan kerja sebagai suatu reaksi emosional yang kompleks. Reaksi emosional ini merupakan akibat dari dorongan, keinginan, tuntutan dan harapanharapan karyawan terhadap pekerjaan yang dihubungkan dengan realita-realita yang dirasakan karyawan, sehingga menimbulkan suatu bentuk reaksi emosional yang berwujud perasaan senang, perasaan puas, atau pun perasaan tidak puas. Kedua, pengertian yang menyatakan bahwa kepuasan kerja adalah suatu sikap karyawan terhadap pekerjaan yang berhubungan dengan situasi kerja, kerja sama antar karyawan, komunikasi antar karyawan dan atasan, imbalan yang diterima dalam kerja, dan hal - hal yang menyangkut faktor fisik dan spikologis. 
Fitria Agustina S, Merry Muspita DU dan Ridwan Iskandar, Analisis Pengawasan Dan Kompetensi Terhadap Kepuasan Kerja Karyawan Melalui Kinerja Pada PT. EAST WEST SEED INDONESIA

\section{Rumusan Masalah}

Berdasarkan uraian di atas, penelitian ini merupakan pengembangan dari beberapa penelitian terdahulu, dimana penelitian ini bermaksud menguji pengaruh pengawasan kerja dan kompetensi kerja terhadap kepuasan kerja karyawan, dengan variabel kinerja karyawan sebagai variabel intervening. Masalah yang diteliti, selanjutnya dapat dirumuskan dalam bentuk pertanyaan sebagai berikut:

1. Apakah pengawasan berpengaruh signifikan terhadap kepuasan kerja karyawan di PT. East West Seed Indonesia?

2. Apakah kompetensi berpengaruh signifikan terhadap kepuasan kerja karyawan di PT. East West Seed Indonesia?

3. Apakah pengawasan berpengaruh signifikan terhadap kinerja karyawan di PT. East West Seed Indonesia ?

4. Apakah kompetensi berpengaruh signifikan terhadap kinerja karyawan di PT. East West Seed Indonesia ?

5. Apakah kinerja karyawan berpengaruh signifikan terhadap kepuasan kerja karyawan di PT. East West Seed Indonesia?

\section{Tujuan Penelitian}

Berdasarkan rumusan masalah diatas, maka tujuan dari penelitian ini adalah untuk:

1. Mengetahui pengaruh pengawasan terhadap kepuasan kerja yang ada pada karyawan di PT. East West Seed Indonesia.

2. Mengetahui pengaruh kompetensi terhadap kepuasan kerja yang ada pada karyawan di PT. East West Seed Indonesia.

3. Mengetahui pengaruh pengawasan terhadap kinerja yang ada pada karyawan di PT. East West Seed Indonesia.

4. Mengetahui pengaruh kompetensi terhadap kinerja yang ada pada karyawan di PT. East West Seed Indonesia

5. Mengetahui pengaruh kinerja karyawan terhadap kepuasan kerja yang ada pada karyawan di PT. East West Seed Indonesia.

\section{Manfaat Penelitian}

Penelitian ini diharapkan dapat bermanfaat bagi semua pihak, antara lain :

1. Sebagai pengalaman dan ilmu pengetahuan yang berharga dalam menambah pengalaman dan juga ilmu pengetahuan, serta dapat menjadi bahan acuan bagi penelitian selanjutnya.

2. Penelitian ini diharapkan bisa menjadi bahan pertimbangan dan masukan bagi PT. East West Seed Indonesia untuk dapat menerapkan kebijakan dan menjadi salah satu strategi dalam meningkatkan kepuasan karyawan dalam bekerja.

3. Bagi akademis, sebagai referensi kepustakaan dan kontribusi bagi pengembangan ilmu pengetahuan di bidang manajemen sumberdaya manusia, khususnya adalah karyawan dalam meningkatkan kepuasan karyawan dalam bekerja.

\section{METODE PENELITIAN \\ Metode Penentuan Lokasi}

Lokasi penelitian dipilih dengan sengaja (purposive) didasarkan atas PT. East West Seed Indonesia adalah perusahaan terbesar Indonesia, yang tersebar di daerah Indonesia termasuk kab. Jember.

\section{Metode Penentuan Responden}

Populasi adalah keseluruhan objek penelitian (Arikunto, 2006). Populasi dalam penelitian ini adalah karyawan di PT. East West Seed Indonesia sebagai individu karyawan yang diteliti kepuasan kerjanya yang berjumlah \pm 700 individu karyawan.

Menurut Sugiyono (2011) penentuan jumlah sampel minimal dalam penelitian, yaitu dua puluh persen (20\%) dari jumlah populasi. Jumlah total karyawan tetap yang bekerja di PT. East West Seed Indonesia adalah 700 karyawan tetap. Dua puluh lima persen ( $28 \%$ )dari 700 responden karyawan yaitu 196 karyawan. Metode penentuan pengambilan sampel responden yang akan diambil yaitu adalah metode simple random sampling yaitu metode pemilihan sampel secara acak sederhana memberikan kesempatan yang sama yang bersifat tak terbatas pada setiap populasi untuk dipilih sebagai sampel

\section{Metode Analisis Data}

Data akan diolah dan dipaparkan berdasarkan prinsip-prinsip statistik deskriptif, sedangkan untuk kepentingan analisis dan pengujian hipotesis digunakan pendekatan statistic inferensial. Analisis yang digunakan untuk menguji hipotesis dalam penelitian ini adalah model persamaan struktural (Structural Equation Modeling atau SEM) dengan menggunakan paket program AMOS (Analysis 
Fitria Agustina S, Merry Muspita DU dan Ridwan Iskandar, Analisis Pengawasan Dan Kompetensi Terhadap Kepuasan Kerja Karyawan Melalui Kinerja Pada PT. EAST WEST SEED INDONESIA

of Moment Structure) versi 20.0. Data yang terkumpul dianalisis dengan analisis SEM yang merupakan penggabungan dari analisis jalur (path analysis) dan model pengukuran (measurement model) yaitu analisis faktor (Confirmatory Factor Analysis). Secara umum, alat analisis utama dalam penelitian ini yaitu alat uji asumsi SEM dan alat uji kecocokan model.

Uji asumsi SEM, Ukuran sampel. disarankan lebih dari 100 atau minimal 5 kali jumlah observasi. Uji normalitas data dipergunakan tingkat signifikasi $5 \%$ (0.05), maka nilai CR yang berada diantara -2.58 sampai dengan $2.58(-2.58 \leq \mathrm{CR} \leq 2.58)$ dikatakan data distribusi normal, baik secara univariate maupun secara multivariate (Ghozali, 2005). Uji Outlier adalah kondisi obervasi dari suatu data yang memiliki karakteristik unik yang terlihat sangat berbeda jauh dari observasiobservasi yang lainnya, dan muncul dalam bentuk nilai ekstrim, baik untuk sebuah variabel tunggal maupun untuk variabel-variabel kombinasi (Ghozali, 2005). Uji multikolinieritas dilakukan untuk mengetahui apakah antara variabel pada model yang sempurna. Nilai determinan yang sangat kecil atau mendekati nol diindikasikan adanya masalah multikolinearitas atau singularitas, sehingga tidak dapat digunakan dalam penelitian (Ghozali 2005).

Uji kecocokan model terdiri dari Goodness of Fit Test dan uji pengaruh (Regression Weight). Ada dua model yang akan diuji secara simultan, yaitu: (1) model pengukuran (measurement model), dan (2) model struktural (structural model).

Langkah-langkah atau prosedur dalam mengaplikasi model persamaan struktural adalah antara lain :

Langkah-1 : membangun model berbasis teori, yang menjelaskan hubungan sebab-akibat dengan justifikasi teoritis dari manajemen sumber daya manusia.

Langkah-2 : pengembangan diagram jalur. Model yang dibangun pada langkah-1, digambarkan dalam bentuk diagram jalur. Konstruksi yang dibangun pada diagram jalur dibedakan menjadi dua konstruksi, yaitu: konstruk eksogen dan konstruk endogen

Langkah-3 : mengkonversi diagram jalur menjadi persamaan model struktural, persamaan struktural diajukan dalam model konseptual penelitian seperti pada Gambar 1. berikut ini:

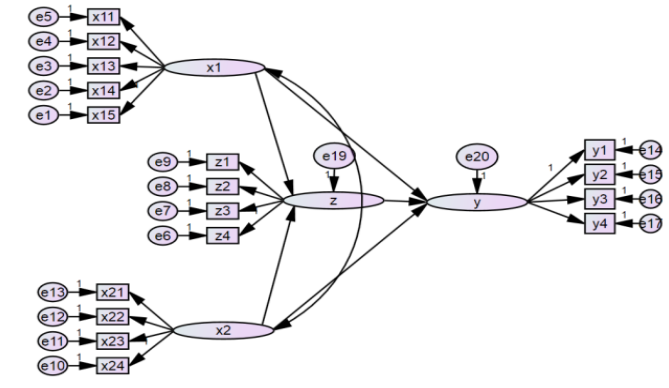

Gambar 1. Formulasi model SEM

Keterangan gambar:

1. Variabel bebas (Laten eksogen):

Indikator pengawasan:

$\mathrm{X} 11$ = Perhatian pimpinan

$\mathrm{X} 12$ = Kemampuan Pimpinan

$\mathrm{X} 13=$ Frekuensi pimpinan memberikan

teguran dan arahan.

$\mathrm{X} 14$ = Kejelasan perintah pimpinan

$\mathrm{X} 15$ = Frekuensi pengawasan

Indikator Kompetensi

$\mathrm{X} 21$ = Pengetahuan

$\mathrm{X} 22$ = Keterampilan

$\mathrm{X} 23$ = Kemampuan

$\mathrm{X} 24=$ Konsep diri

2. Variabel terikat (Laten endogen):

Indikator Kinerja:

Z1= Kuantitas kerja

$\mathrm{Z} 2=$ Kualitas kerja

$\mathrm{Z} 3=$ Kreativitas kerja

Z4= Profesional Kerja

Indikator Kepuasan Kerja:

$\mathrm{Y} 1=$ Prestasi kerja

Y2= Penghargaan Kerja

Y3= Kecocokan kerja

Y4= Tanggung Jawab

Langkah-4 : Pemilihan matriks input dan teknik estimasi model. Matriks input dalam SEM dalam penelitian ini adalah matriks kovarians

Langkah-5 : Estimasi model dengan program Analysis of Moment Structure (AMOS 20 Profesional). Estimasi identifikasi persamaan model dilakukan dengan menggunakan standard error yang besar untuk sebuah koefisien atau lebih, atau dengan kata lain, menggunakan korelasi yang tinggi di antara koefisien estimasi.

Langkah-6: Evaluasi model melalui ukuran goodness of fit, yaitu :

Tabel 1. Pengujian Goodness of Fit

\begin{tabular}{|c|c|c|}
\hline Kriteria & Nilai Cut-Off & $\begin{array}{c}\text { Keteranga } \\
\mathrm{n}\end{array}$ \\
\hline Chi Square & $\begin{array}{c}\text { Diharapkan kecil. } \\
\text { Prob. }>0,05\end{array}$ & Good Fit \\
\hline $\begin{array}{c}\text { Significance } \\
\text { Probability }\end{array}$ & $\geq 0,05$ & Good Fit \\
\hline
\end{tabular}


Fitria Agustina S, Merry Muspita DU dan Ridwan Iskandar, Analisis Pengawasan Dan Kompetensi Terhadap Kepuasan Kerja Karyawan Melalui Kinerja Pada PT. EAST WEST SEED INDONESIA

\begin{tabular}{|c|c|c|}
\hline RMSEA & $\leq 0,08$ & Good Fit \\
\hline AGFI & $\geq 0,90$ & Good Fit \\
\hline GFI & $\geq 0,90$ & \\
\hline CFI & $\geq 0,90$ & Good Fit \\
\hline CMIN/DF & $\leq 2$ atau 3 & Good Fit \\
\hline TLI & $\geq 0,90$ & Good Fit \\
\hline
\end{tabular}

Sumber : Ghozali( 2005).

Langkah -7. Interpretasi dan Modifikasi Model Langkah terakhir adalah menginterpretasikan model dan memodifikasi model bagi model - model yang tidak memenuhi syarat pengujian yang dilakukan. Setelah model diestimasi, residual kovariansnya haruslah kecil atau mendekati nol dan distribusi frekuensi dari kovarians residual harus bersifat simetrik. Batas keamanan jumlah residual yang dihasilkan oleh model adalah 5\%. Nilai residual values yang lebih besar atau sama dengan 2,58 diinterpretasikan sebagai signifikan secara statis pada tingkat $1 \%$.

\section{HASIL DAN PEMBAHASAN Uji Validitas (CFA)}

Uji validitas konstruk dilakukan bertujuan untuk melihat indikator yang layak untuk mewakili konstruk pada penelitian ini. Pengujian dilakukan dengan menggunakan confirmatory factor analysis (CFA) pada masing-masing variabel laten dengan nilai loading factor $(\lambda) \geq 0.40$ dan memenuhi kriteria goodness of fit.

\section{Uji Asumsi SEM}

1. Ukuran sampel

Ukuran sampel disarankan lebih dari $100 \mathrm{~s} / \mathrm{d}$ 200. Penelitian ini menggunakan dari 200 responden menjadi 181.

2. Normalitas data

Normalitas data untuk mengukur kenormalan data secara univariat maupun multivariat. Nilai critical ratio yaitu dengan nilai 1,834 terletak diantara $-2,58 \leq \mathrm{CR} \leq 2,58$

3. Hasil uji Outlier

Uji outlier merupakan penelusuran data yang ekstrim yang berbeda dengan data pengamatan lainnya. Sebuah data dikatakan sebagai kategori outlier jika mempunyai nilai p1 dan p2 pada nilai mahalanobis distance kurang dari 0.05

4. Multikolineritas

Gejala multikolineritas dapat diindikasikan dari determinan mastriks varians - kovarians data variabel eksogen. Hasil uji penelitian menunjukkan bahwa nilai determinan matriks varians-kovarians $=3,847$ jauh diatas nol.

\section{Analisis SEM}

Hasil analisis dan estimasi model dapat dijelaskan pada Gambar 2. berikut ini:

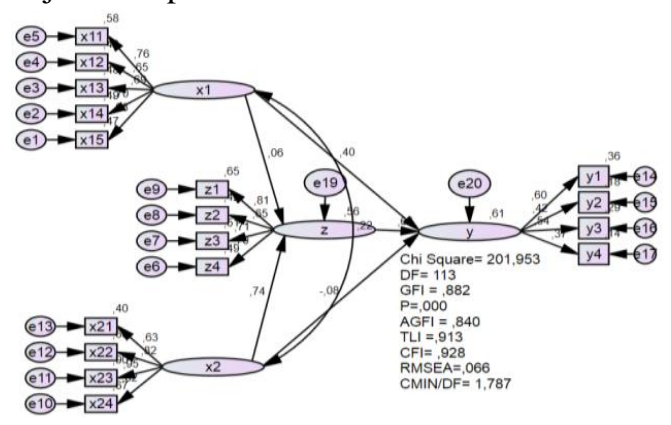

Gambar 2. Hasil Estimasi Model

\section{Uji Kesesuaian Model}

Tabel 3. Hasil Pengujian Goodness of Fit

\begin{tabular}{|l|l|l|l|}
\hline Kriteria & $\begin{array}{l}\text { Nilai } \\
\text { Cut-Off }\end{array}$ & $\begin{array}{l}\text { H. } \\
\text { Analisis }\end{array}$ & Ket \\
\hline Chi Square & $\begin{array}{l}\text { Diharap } \\
\text { kan } \\
\text { kecil. } \\
\text { Prob } \\
0,05\end{array}$ & 201,953 & Good fit \\
\hline DF & & 113 & - \\
\hline $\begin{array}{l}\text { Sig.Probabi } \\
\text { lity }\end{array}$ & $\geq 0,05$ & 0,00 & Marginal \\
\hline RMSEA & $\leq 0,08$ & 0,06 & Good Fit \\
\hline GFI & $\geq 0,90$ & 0,882 & Marginal \\
\hline AGFI & $\geq 0,90$ & 0,840 & Marginal \\
\hline CMIN/DF & $\leq 2$ atau & 1,7 & Good Fit \\
\hline TLI & $\geq 0,90$ & 0,913 & Good Fit \\
\hline CFI & $\geq 0,90$ & 0,928 & Good Fit \\
\hline
\end{tabular}

Sumber: Data diolah 2015

Uji terhadap kesesuai model menunjukkan bahwa model ini sesuai (fit), karena hampir semua cut off value indikator uji dapat terpenuhi. Kriteria goodness of fit menunjukkan bahwa kriteria yang memiliki nilai kriteria yang sesuai (fit) yaitu TLI, CFI, CMIN/DF dan RMSEA mencapai nilai 0.90 . Meskipun terdapat tiga variabel uji yang dibawah cut off value namun tidak terlalu signifikan perbedaannya yaitu kriteria GFI sebesar 0.88 menunjukkan tingkat penerimaan marginal, tetapi model ini tetap dapat diterima karena rentang nilai GFI yang merupakan ukuran non statistical masih mendekati 0.90 sedangkan AGFI juga menunjukkan tingkat peneriamaan marginal, namun karena AGFI sebesar 0.84 merupakan adjusted goodness of fit maka rentang nilai mendekati 0.90 masih dapat diterima.

Menurut Ghozali (2008) model SEM merupakan model recursive (tidak ada hubungan 
Fitria Agustina S, Merry Muspita DU dan Ridwan Iskandar, Analisis Pengawasan Dan Kompetensi Terhadap Kepuasan Kerja Karyawan Melalui Kinerja Pada PT. EAST WEST SEED INDONESIA

regresi reciprocal antar variabel laten) sehingga dengan jumlah sampel yang banyak dalam penelitian ini 181 responden menyebabkan chisquare sangat sensitive terhadap jumlah sampel atau dengan kata lain semakin besar sampel maka akan semakin signifikan.

Dengan demikian uji kelayakan model SEM sudah memenuhi syarat penerimaan dan oleh karena itu dengan terpenuhinya beberapa model yang lain maka model ini dapat diterima.

\section{Uji Kausalitas (Uji Hipotesis)}

Pengujian hipotesis dimaksudkan untuk menguji hipotesis-hipotesis yang diajukan pada bab 2. Pengujian hipotesis ini dilakukan dengan menganalisis nilai $\mathrm{CR}$ dan nilai $\mathrm{P}$ seperti terlihat pada Tabel 4, lalu dibandingkan dengan batasan statistik yang diisyaratkan, yaitu diatas 2.0 untuk C.R dan dibawah 0.05 untuk nilai Probability, apabila hasil olah data menunjukkan nilai yang memenuhi syarat tersebut, maka hipotesis penelitian yang diajukan dapat diterima, selanjutnya pembahasan mengenai pengujian hipotesis akan dilakukan secara bertahap sesuai dengan urutan hipotesis yang telah diajukan.

Tabel 4. Pengujian Goodness of Fit

\begin{tabular}{|c|c|c|c|c|}
\hline \multicolumn{3}{|c|}{ Pengaruh Variabel } & C.R & $\mathrm{P}$ \\
\hline Kinerja & Thd & Pengawasan & 0,813 & 0,416 \\
\hline Kinerja & Thd & Kompetensi & 7,805 & $* * *$ \\
\hline $\begin{array}{c}\text { Kepuasan } \\
\text { kerja }\end{array}$ & Thd & Pengawasan & 3,697 & $* * *$ \\
\hline $\begin{array}{c}\text { Kepuasan } \\
\text { Kerja }\end{array}$ & Thd & Kompetensi & $-0,530$ & 0.596 \\
\hline $\begin{array}{l}\text { Kepuasa } \\
\text { n Kerja }\end{array}$ & Thd & Kinerja & 3,592 & $* * *$ \\
\hline
\end{tabular}

Sumber: Data diolah 2015

Berdasarkan Tabel 4, menunjukkan bahwa pengawasan (X1) terhadap Kinerja (Z) tidak berpengaruh signifikan dan kompetensi (X2) terhadap kinerja berpengaruh signifikan dengan $\mathrm{p}$ value $=0.000$ (hipotesis 3 ditolak dan hipotesis 4 diterima), selanjutnya pengawasan (X1) terhadap kepuasan kerja (Y) dan kompetensi (X2) terhadap kepuasan kerja (Y) (hipotesis 1 diterima dan hipotesis 2 ditolak) sedangkan kinerja (Z) terhadap kepuasan kerja (Y) signifikan dengan $\mathrm{p}$ value sebesar 3,592 lebih kecil dari 0.05 yaitu 0,000 (hipotesis 5 diterima).

\section{Pengaruh Langsung \& Tidak Langsung}

Analisis pengaruh ditujukan untuk melihat seberapa kuat pengaruh suatu variabel dengan variabel lainnya baik secara langsung, maupun secara tidak langsung. Interpretasi dari hasil ini akan memiliki arti yang penting untuk mendapatkan suatu pemilihan strategi yang jelas. Sesuai dengan kajian teoritis dan hasil pengujian hipotesis sebelumnya pengawasan, kompetensi dan kinerja karyawan akan memiliki efek langsung maupun tidak langsung terhadap kepuasan kerja karyawan. Pengaruh tidak langsung dari variabel tersebut adalah dengan terlebih dahulu melewati kinerja, yang selanjutnya berpengaruh terhadap kepuasan kerja karyawan.

Sesuai dengan kajian teoritis dan hasil pengujian hipotesis sebelumnya pengawasan, kompetensi dan kinerja karyawan akan memiliki efek langsung maupun tidak langsung terhadap kepuasan kerja karyawan. Pengaruh tidak langsung dari variabel tersebut adalah dengan terlebih dahulu melewati kinerja, yang selanjutnya berpengaruh terhadap kepuasan kerja karyawan.

Hasil pengujian pengaruh langsung dan tidak langsung tersebut dapat diringkas pada Tabel 5 sebagai berikut:

Tabel 5. Pengaruh langsung dan tidak langsung.

\begin{tabular}{|l|l|l|l|}
\hline & $\begin{array}{c}\text { Pengaruh } \\
\text { Langsung } \\
\text { (a) }\end{array}$ & $\begin{array}{c}\text { Pengaruh } \\
\text { tidak } \\
\text { langsung } \\
\text { (b) }\end{array}$ & $\begin{array}{c}\text { Total } \\
(\mathrm{a}+\mathrm{b})\end{array}$ \\
\hline Pengawasan & 0,40 & $\begin{array}{l}0,06 * 0,6 \\
0 \\
=0,036\end{array}$ & 0,436 \\
\hline Kompetensi & $-0,08$ & $\begin{array}{l}0,74 * 0,6 \\
0=0,444\end{array}$ & 0,364 \\
\hline
\end{tabular}

\section{PEMBAHASAN}

Hasil analisis penelitian ini menunjukkan bahwa pengaruh pengawasan, kompetensi terhadap kinerja, serta pengaruh pengawasan, kompetensi dan kinerja terhadap kepuasan kerja menunjukkan hasil yang berbeda. Untuk menjelaskan perbedaan masing-masing pengaruh tersebut maka akan diuraikan perpaduan antara temuan studi empiris hasil penelitian yang telah diuji secara statistik ini dengan dengan teori dan temuan empiris hasil penelitian sebelumnya sehingga diperoleh suatu konstruk teori baru dan pengembangan teori yang sudah ada.

\section{Pengaruh Pengawasan (X1) Terhadap Kinerja ( $Z$ )}

Hasil pengujian kausalitas menghasilkan temuan bahwa pengawasan tidak berpengaruh terhadap kinerja. Hal ini tidak sesuai dengan koefisien jalur dan nilai CR sebesar 0,813 serta taraf signifikansi 0.416, berdasarkan nilai tersebut maka dapat dijelaskan bahwa variabel pengawasan tidak berpengaruh signifikan dengan demikian hipotesis 1 yang menyatakan pengawasan berpengaruh signifikan terhadap 
Fitria Agustina S, Merry Muspita DU dan Ridwan Iskandar, Analisis Pengawasan Dan Kompetensi Terhadap Kepuasan Kerja Karyawan Melalui Kinerja Pada PT. EAST WEST SEED INDONESIA

kinerja ditolak, atau tidak berpengaruh signifikan.

Hasil ini juga diperkuat dari informasi yang diperoleh oleh peneliti dari karyawan perusahaan yang menyatakan bahwa pimpinan dari perusahaan dalam melaksanakan frekuensi pengawasan itu kadang kadang dilaksanakan pimpinan. Pihak perusahaan PT. East West Seed Indonesia telah membuat jadwal pengawasan, yang harus dilaksanakan oleh pimpinan dalam mengawasi pekerjaan yang dilakukan oleh para karyawan yaitu dalam seminggu, pimpinan diwajibkan melaksanakan pengawasan 3 kali, yaitu pada hari senen, kamis dan jumat. Namun hal tersebut tidak terlaksana dengan baik oleh pimpinan. Hal ini merupakan salah satu alasan yang kuat mengapa pengawasan tidak berpengaruh signifikan terhadap kinerja karyawan.

Pengawasan menurut Siagian (2007) menyatakan bahwa pengawasan adalah proses pengamatan dari pelaksanaan seluruh kegiatan organisasi untuk menjamin agar semua pekerjaan sesuai dengan renacana sebelumnya, yang artinya pimpinan mengawasi semua para karyawan pada saat karyawan melakukan pekerjaan mereka, agar tidak terjadi kesalalahan dalam pekerjaan, dan dapat meningkatkan kinerja dari para karyawan, dengan mengawasi pekerjaan karyawan berharap agar tidak terjadi kesalahan maupun tindakan penyelewangan pada karyawan. Pengawasan adalah suatu aktivitas pembinaan yang direncanakan untuk membantu karyawan lainnya dalam melaksanakan pekerjaan mereka secara efektif.

\section{Pengaruh Kompetensi (X2) Terhadap Kinerja (Z)}

Hasil pengujian hipotesis menghasilkan temuan bahwa kompetensi berpengaruh secara langsung terhadap kinerja. Hal ini sesuai dengan koefisien jalur dan nilai C.R sebesar 7,805 serta taraf signifikansi 0.000 lebih kecil dari 0.05 , berdasarkan nilai tersebut maka dapat dijelaskan bahwa variabel kompetensi berpengaruh secara langsung dan signifikan terhadap kinerja dan menerima hipotesis 4 yang menyatakan kompetensi berpengaruh signifikan terhadap kinerja.

Hal ini menunjukkan kesesuaian data yang didapat oleh peneliti dari lapangan yaitu pada pernyataan karyawan PT. East West Seed Indonesia menunjukkan hasil dari setiap indikator - indikator kompetensi yaitu indikator konsep diri dari karyawan, kemampuan karyawan, keterampilan karyawan dan pengetahuan karyawan menunjukkan hasil kriteria sering, yang artinya dari semua indikator tersebut, karyawan perusahaan PT. East West Seed Indonesia memiliki konsep diri, kemampuan, keterampilan, dan pengetahuan didalam melaksanakan pekerjaanya, dengan demikian hal tersebut dapat meningkatkan kinerja dari para karyawan.

Penelitian ini juga didukung oleh Mulyasa (2003), yang menyatakan bahwa kompetensi adalah kemampuan dan karakteristik yang dimiliki oleh seorang karyawan berupa pengetahuan, sikap (konsep diri) yang diperlukan dalam tugas dan jabatannya, yang artinya kompetensi sebagai penguasaan terhadap suatu tugas, keterampilan, dan sikap, yang diperlukan untuk menunjang keberhasilan dan memberikan kinerja yang unggul.

\section{Pengaruh Pengawasan (X3) Terhadap Kepuasan Kerja (Y)}

Hasil pengujian hipotesis menghasilkan temuan bahwa pengawasan berpengaruh signifikan terhadap kepuasam kerja. Hal ini sesuai dengan koefisien jalur dan nilai CR sebesar 3,697 serta taraf signifikansi 0.000, berdasarkan nilai tersebut maka dapat dijelaskan bahwa variabel pengawasan berpengaruh secara langsung dan signifikan terhadap kepuasan kerja dan menerima hipotesis 1 yang menyatakan pengawasan berpengaruh signifikan terhadap kepuasan kerja.

Dari penelitian ini, menurut peneliti hal yang mempengaruhi pengawasan terhadap kepuasan kerja karyawan yaitu terletak pada perhatian pimpinan, kemampuan pimpinan, pimpinan memberikan arahan dan koreksi serta kejelasan perintah yang di berikan pimpinan. Kepuasan kerja dapat ditingkatkan melalui perhatian dan hubungan yang baik dari pimpinan kepada karyawan, sehingga karyawan akan merasa bahwa dirinya merupakan bagian yang penting dari perusahaan. Selain itu, ketika karyawan mengalami permasalahan dalam pekerjaanya, diharapkan pimpinan mampu memberikan arahan yang baik serta koreksi kepada karyawan dalam melakukan perbaikan pada pekerjaanya.

Menurut Handoko (2007) pengawasan adalah segala usaha dan kegiatan untuk mengetahui dan menilai kenyataan yang sebenarnya mengenai pelaksaan tugas atau kegiatan apakah sesuai dengan yang semestinya atau tidak dan pengawasan adalah proses pengamatan dari pelaksanaan kegiatan pekerjaan karyawan untuk menjamin agar semua pekerjaan yang sedang dilakukan berjalan sesuai rencana yang telah ditetapkan. dan pengawasan adalah suatu proses kegiatan pimpinan yang sistematis untuk membandingkan, memastikan dan 
Fitria Agustina S, Merry Muspita DU dan Ridwan Iskandar, Analisis Pengawasan Dan Kompetensi Terhadap Kepuasan Kerja Karyawan Melalui Kinerja Pada PT. EAST WEST SEED INDONESIA

menjamin bahwa tujuan dan sasaran serta kegiatan karyawan terlaksana dengan baik sesuai dengan standar, rencana, instruksi dan ketentuan-ketentuan yang telah ditetapkan perusahaan pada karyawan serta mengambil tindakan perbaikan dan pencegahan yang diperlukan, guna pemanfaatan sumber daya yang paling efektif dan efisien.

\section{Pengaruh Kompetensi (X2) Terhadap} Kepuasan Kerja (Y)

Hasil pengujian hipotesis ke 2 menunjukan bahwa kompetensi tidak berpengaruh terhadap kepuasan kerja hal ini dapat dilihat dari nilai C.R yang mencapai nilai sebesar -,530 dengan nilai probabilitas 0,596. Dengan demikian hipotesis ke 2 ditolak dan tidak berpengaruh signifikan. Hal ini dapat dijelaskan dengan beberapa teori yang menjelasakan bahwa kompetensi adalah keterampilan yang dibutuhkan untuk menyelesaikan suatu pekerjaan atau menjalankan suatu jabatan, dengan pengetahuan, keterampilan, kemampuan dan konsep diri karyawan. Jadi dengan demikian pengetahuan, keterampilan, kemampuan, konsep diri karyawan tersebut karyawan bisa menyelesaikan pekerjaan dengan benar.

Peneliti menyimpulkan mengapa dalam penelitian ini pada variabel kompetensi tidak berpengaruh signifikan terhadap kepuasan kerja, karena kompetensi yang dimiliki karyawan tidak mampu secara langsung mempengaruhi kepuasan kerja, jika tidak menunjukkan hasil dari pekerjaan yang karyawan lakukan atau dengan kata lain kinerja dari karyawan tersebut. Kesimpulannya variabel kompetensi harus melalui variabel kinerja terlebih dahulu barulah dapat dilihat bentuk kepuasan kerja dari karyawan.

Menurut Luthans (2006) yang mengemukakan kompetensi adalah suatu kemampuan yang dilandasi oleh keterampilan dan pengetahuan yang didukung oleh sikap kerja karyawan serta penerapannya dalam melaksanakan tugas dan pekerjaan ditempat kerja yang mengacu pada persyaratan yang ditetapkan perusahaan sehingga karyawan mengeluarkan kinerja yang baik. Dengan demikian, indikator - indikator yang digunakan peneliti dalam variabel kompetensi tidak mempengaruhi kepuasan kerja karyawan.

\section{Pengaruh Kinerja (Z) Terhadap Kepuasan Kerja (Y)}

Hasil pengujian hipotesis menghasilkan temuan bahwa kinerja berpengaruh secara langsung terhadap kepuasan kerja. Hal ini sesuai dengan koefisien jalur dan nilai CR sebesar 3,592 serta taraf signifikansi 0.000 lebih kecil dari 0.05 , berdasarkan nilai tersebut maka dapat dijelaskan bahwa variabel kepuasan kerja berpengaruh secara langsung dan signifikan terhadap kinerja dan menerima hipotesis 5 yang menyatakan kinerja berpengaruh signifikan terhadap kepuasan kerja.

Menurut peneliti ketika kinerja dari karyawan tinggi maka kepuasan kerja dari karyawan tersebut pun akan tinggi pula. Karyawan yang memiliki kinerja tinggi dan kepuasan kerja yang baik, maka karyawan akan menghasilkan kuantitas pekerjaan yang besar, karyawan akan menjadi lebih profesional dalam bekerja dan akan mengeluarkan kreativitas atau ide-ide yang baru pada dalam pekerjaannya. Maka dengan demikian karyawan akan menjadi karyawan yang berpestasi, memiliki penghargaan kerja yang baik, cinta pada pekerjaanya dan memiliki nilai tanggung jawab yang besar pada setiap pekerjaan yang karyawan lakukan.

Kinerja merupakan perilaku nyata yang ditampilkan setiap orang sebagai prestasi kerja yang dihasilkan oleh karyawan sesuai dengan perannya dalam perusahaan. Kinerja karyawan merupakan suatu hal yang penting dalam upaya perusahaan untuk mencapai tujuan. Karyawan dengan tingkat kinerja yang tinggi, akan memiliki kepuasan kerja yang tinggi juga, maka karyawan akan menunjukkan sikap yang positif terhadap pekerjaanya, sebaliknya jika karyawan dengan tingkat kinerja yang rendah, maka karyawan juga akan memiliki tingkat kepuasan kerja yang rendah akan pekerjaannya dan tidak puas dengan pekerjaanya, dan karyawan pastinya tidak akan segan menunjukkan sikap yang negatif terhadap pekerjaanya.

Seorang karyawan dapat dikatakan memiliki kinerja yang tinggi jika karyawan memiliki kepuasan kerja yang tinggi pula, dan puas dalam pekerjaanya, apabila karyawan tersebut menyukai dan menghargai pekerjaanya serta memiliki dan memberikan kesan yang positif terhadap pekerjaannya, maka karyawan akan memberikan kinerja yang baik dan superior dalam menyelesaikan suatu pekerjaan yang karyawan lakukan. PT. East West Seed Indonesia menyatakan bahwa perusahaan ini memiliki karyawan yang memiliki kinerja yang tinggi, dan pihak perusahaan juga menyatakan bahwa setiap 6 bulan sekali perusahaan akan mengevaluasi kinerja dari karyawannya.

\section{KESIMPULAN}

1) Pengawasan tidak berpengaruh signfikan terhadap kinerja karyawan PT. East West 
Fitria Agustina S, Merry Muspita DU dan Ridwan Iskandar, Analisis Pengawasan Dan Kompetensi Terhadap Kepuasan Kerja Karyawan Melalui Kinerja Pada PT. EAST WEST SEED INDONESIA

Seed Indonesia dengan nilai $\mathrm{CR}=0,813$ dan $\mathrm{P}$ value $=0.416$.

2) Kompetensi berpengaruh signifikan terhadap kinerja karyawan PT. East West Seed Indonesia dengan nilai $\mathrm{CR}=7,805$ dan $\mathrm{P}$ value $=0.000$.

3) Pengawasan berpengaruh langsung dan signifikan terhadap kepuasan kerja karyawan PT. East West Seed Indonesia dengan nilai $\mathrm{CR}=3,697$ dan $\mathrm{P}$ value $=0.000$.

4) Kompetensi tidak berpengaruh signifikan terhadap kepuasan kerja karyawan PT. East West Seed Indonesia dengan nilai $\mathrm{CR}=-$ 0,530 dan $\mathrm{P}$ value $=0,596$.

5) Kinerja berpengaruh signifikan terhadap kepuasan kerja karyawan PT. East West Seed Indonesia dengan nilai $\mathrm{CR}=3,592$ dan $\mathrm{P}$ value $=0.000$.

\section{SARAN}

Berdasarkan pada pembahasan dan kesimpulan maka dapat diajukan beberapa saran sebagai berikut:

1) Bagi PT. East West Seed Indonesia: beberapa hal yang harus diperhatikan oleh pimpinan perusahaan yaitu lebih meningkatkan mutu pengawasan dan dapat meningkatkan kompetensi yang ada pada setiap karyawannya serta kinerja dan juga kepuasan kerja untuk semua karyawan di PT. East West Seed Indonesia.

2) Bagi peneliti selanjutnya: beberapa hal yang harus diperhatikan oleh peneliti selanjutnya antara lain pemilihan populasi dan sampel yang sesuai dengan tujuan penelitian, teknik penentuan jumlah sampel dan pengambilan sampel yang sesuai dengan kebutuhan, serta pemilihan teknik analisis yang tepat. Dan diharapkan peneliti juga dapat menentukan indikator indikator yang tepat dalam suatu variabel yang akan menjadi penelitian selanjutnya.

\section{IMPLIKASI PENELITIAN}

Berdasarkan hasil penelitian ini peneliti merekomendasikan antara lain:

1. Disarankan kepada PT. East West Seed Indonesia untuk memperhatikan frekuensi pengawasan yang dilakukan oleh pimpinan pada karyawannya, sehingga pimpinan dapat menjalankan pengawasan sesuai dengan jadwal yang sudah ditentukan oleh perusahaan. Pimpinan berperan aktif dalam menjalankan pengawasan secara langsung dan melakukan pengawasan sesering mungkin. Dengan demikian, pimpinan perusahaan dapat memperhatikan secara langsung semua aktivitas pekerjaan karyawan.

2. Disarankan kepada PT. East West Seed Indonesia untuk meningkatkan kompetensi karyawan yang sudah ada, guna untuk meningkatkan kinerja serta kepuasan karyawan.

3. Disarankan kepada PT. East West Seed Indonesia untuk meningkatkan evaluasi kinerja karyawan yang sudah ada. Dari form evaluasi kinerja karyawan yang di dapat oleh peneliti dari pihak perusahaan, peneliti merekomendasikan untuk menambahkan kriteria penilaian dalam evaluasi kinerja yaitu kreativitas kerja dan profesional kerja.

4. Disarankan kepada PT. East West Seed Indonesia, dalam mengevaluasi kepuasan kerja karyawan dapat dilakukan dengan cara mengevaluasi kepuasan kerja karyawan dengan melihat pencapaian prestasi dari karyawan, penghargaan yang didapat karyawan, kecocokan karyawan dengan pekerjaannya serta dari tingkat tanggung jawab pekerjaan yang dilakukan oleh karyawan.

\section{DAFTAR PUSTAKA}

Arikunto S. 2006. Prosedur Penelitian Suatu Pendekatan Praktik. Edisi Ke 6. Jakarta: Reneka Cipta.

Bambang, W. 2002. Manajemen Sumber Daya Manusia. Bandung. Sulita.

Damayanti, A.P. dan Sumaryati, S. 2013. Pengaruh Kompensasi dan Motivasi Kerja terhadap Kinerja Karyawan Perusahaan Daerah Air Minum (PDAM) Surakarta. Jupe UNS. 2(1):155-168.

Eko. 2004. Kompetensi Resep Ajaib Artikel. Jakarta.

Ghozali I. 2005. Aplikasi Analisis Multivariate dengan program SPSS. Semarang: Badan Penerbit Universitas Diponegoro.

Hasibuan. 2006. Manajemen Sumber Daya Manusia. Jakarta: Bumi Aksara.

Hamermesh, D. 2001. The Changing Distribution of Job Satisfaction. University of Wisconsin Press Stable. Journal of Human Resources, Vol. 36, No. 1.

Lund Daulatram B., 2003., "Organizational Culture and Job Satisfaction", Journal of Business \& Industrial Marketing, Vol.18 No.3 P. 219-236.

Luthans, F. 2006. Perilaku Organisasi. Edisi kesepuluh. Penerbit Andi Offset. 
Fitria Agustina S, Merry Muspita DU dan Ridwan Iskandar, Analisis Pengawasan Dan Kompetensi Terhadap Kepuasan Kerja Karyawan Melalui Kinerja Pada PT. EAST WEST SEED INDONESIA

Nitisemito. 2002. Manajemen Sumber Daya Manusia. Cetakan Kesembilan. Edisi ke Empat. Jakarta. Ghalia Indonesia.

Palan, R. 2007. Competency Management. Teknik Mengimplementasikan Manajemen SDM Berbasis Kompetensi untuk Meningkatkan Daya Saing Organisasi. Penerjemah: Octa Melia Jalal. Penerbit PPM. Jakarta.

Siagian, S. 2007. Manajemen Sumberdaya Manusia. Cetakan Kesembilan. Bumi Aksara, Jakarta.
Sugiyono. 2011. Statistik Untuk Penelitian, Alfabeta, Bandung.

Sutrisno E. 2011. Manajemen Sumber Daya Manusia. Jakarta: Kencana

Sutarto. 2012. Psikologi Industri dan Organisasi. Jakarta. Kharisma Putra Utama.

Umar, H. 2001. Riset Sumber Daya Manusia dalam Organisasi. Jakarta. Gramedia Pustaka Utama 